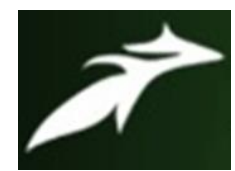

Sidharth Dash et al, International Journal of Advances in Agricultural Science and Technology,

Vol.8 Issue.1, January-2021, pg. 52-65

ISSN: 2348-1358

Impact Factor: 6.057

NAAS Rating: 3.77

\title{
A Study on the Impact of Farmer Producer Organisations on its Member Respondents in Puri District of Odisha
}

\author{
Sidharth Dash; Syed H. Mazhar \\ Department of Agricultural Extension and Communication, Naini Agricultural Institute, SHUATS, Prayagraj-211007 \\ DOI: 10.47856/ijaast.2021.v08i1.008
}

Abstract: India has over 92 million small holdings or nearly $21 \%$ of the world's small holdings of 450 million, the second largest after China. Collectivization of producers, especially small and marginal farmers, into producer organizations is emerging as one of the most effective pathways to address the many challenges of agriculture and most importantly, improved access to investments, technology and inputs and markets. The present study entitled "Impact analysis of Farmer Producer Organizations (FPOs) on vegetable farmers of Puri district of "Odisha" was carried out from September 2019 to July 2020 with a perceptual analysis among the member respondents (vegetable farmers) of FPOs of Puri district with a total sample size of 131 respondents selected through proportionate random sampling from three active FPOs comprised of 1310 vegetable farmers of the district in an intention to find out the socio economic profiles of members of farmer producer organisation, its impact and constraints faced by the respondents. The study found that only 8.41 percent (11 numbers) of the respondents were illiterate and rest were having education from primary level to graduation and above. The result revealed that only 18.32 percent (24 numbers) of the respondents had high extension contact whereas 63.36 percent (83 numbers) and 18.32 percent (24 numbers) of the respondents had medium and low level of extension contact respectively. The impact analysis of FPOs found higher mean score in knowledge development $($ mean $=2.11)$ followed by social development $($ mean=1.98). A majority of 76.34 percentage of member respondents showed medium level technical development followed by 14.5 percentage in high level and only 9.16 percentage in low level of technical development. The members indicated a remarkable increase in their production (mean score=2.504) followed by lower input cost (2.481) and decrease in transaction cost (2.458. The independent variables like average annual income and extension contact showed positive significant association with the technical development due to FPO. About 96.18 percentage member respondents fully agreed on prevalence of insufficient storage facilities followed by lack of awareness on importance of grading and packaging (77.86\%) and computer Illiteracy (74.05\%) while 66.36 and 55.73 percentage member respondents agreed on the constraints, insufficient training and services and difficulties in following recommended practices respectively. The member respondents perceived major marketing constraints (mean score= 2.55) followed by technical constraints (2.418) and economic constraints (2.35). Due to major marketing constraints, the farmers were still far away in getting remunerative prices for their produce, which need to be restructured to make higher impact on vegetable farmers. 


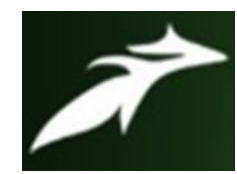

Sidharth Dash et al, International Journal of Advances in Agricultural Science and Technology, Vol.8 Issue.1, January-2021, pg. 52-65

ISSN: 2348-1358

Impact Factor: 6.057

NAAS Rating: 3.77

\section{Introduction:}

Agriculture is the primary sector of the economy and primary source of livelihood for about 58 per cent of India's population. At the time of Indian independence this sector had biggest share in the Gross Domestic Product of India. But year by year its contribution goes on declining and currently it contributes only $17 \%$ of Indian GDP at current prices. India's production of food grains has been increasing every year, and India is among the top producers of several crops such as wheat, rice, pulses, sugarcane and cotton. It is the highest producer of milk and second highest producer of fruits and vegetables.

There are several legal entities which aim to help farmers reap benefits of economies of scale via aggregation like farmer cooperatives, farmers clubs, farmer interest groups, etc. Farmer Producer Organizations (FPOs) are one such farmers ${ }^{e e}$ aggregate. FPOs are registered under the Indian Companies Act, 1956. Producer Organizations therefore are supposed to be non-political entities aimed at providing business services to smallholder farmer members, founded on the principal of self-reliance (Onumah et al., 2007).

The basic purpose envisioned for the FPOs is to collectivize small farmers for backward linkage for inputs like seeds, fertilizers, credit, insurance, knowledge and extension services; and forward linkages such as collective marketing, processing, and market-led agriculture production (Mondal, 2010). To facilitate this process, the Small Farmerse Agribusiness Consortium (SFAC) was mandated by Department of Agriculture and Cooperation, Ministry of Agriculture, Govt. of India, to support the state governments in the formation of Farmer Producer Organizations (FPOs). The aim is to enhance farmers ${ }^{\text {ee }}$ competitiveness and increase their advantage in emerging market opportunities. The year 2014 was observed as the "Year of Farmer Producer Organisations", and slowly but surely, the concept is catching on. The FPO"s major operations will include supply of seed, fertilizer and machinery, market linkages, training and networking and financial and technical advice. Vision of the FPO is to build a prosperous and sustainable member- owned producer organization that enable farmers to enhance productivity through efficient, cost-effective and sustainable resource use and realize higher returns for their produce, through collective action.

\section{Materials and Methods:}

In the present study, following non-parametric and parametric tools and techniques were used in the analysis of data using the standard formula.

(i) Frequency and Percentage

(ii) Mean ( )

(iii) Standard Deviation(б)

(iv) Mean score

(v) Ranking 
(vi) Correlation and Correlation Coefficient

(vii) Regression analysis

\section{Frequency and percentage:}

The number of individuals or observations in each class of attributes/variables is called frequency of that class of variable. The arrangement of Frequencies in different classes of a variable is called The Frequency distribution of the variables (Gupta, 2000).

\section{Mean:}

Mean is simplest and relatively stable measure of central tendency. The mean reflects and is affected by every score in the distribution.

When the data are expressed in a frequency distribution (grouped), the mean is calculated by using the following formula-

Where,

$$
X=\frac{\sum_{i=1}^{N} f i x i}{N}
$$

$$
\begin{aligned}
& \mathrm{X}=\text { Mean of the observation. } \\
& \text { fi }=\text { Frequency of the class. } \\
& \mathrm{x}_{\mathrm{i}} \quad=\text { Mid value of the class. } \\
& \mathrm{N}=\text { Total number of observation }
\end{aligned}
$$

\section{Standard deviation:}

Standard deviation (SD) of a set of observation is the square root of the arithmetic mean of the squares of the deviations. The deviations being measured from the arithmetic mean of the distributions. It is commonly denoted by the symbol $\sigma$ (Sigma). To measure the average deviation from the standard value of the data standard deviation is used. It is less affected by sampling errors and is a more stable measure of dispersion.

\section{Mean Score:}

It is also another simple comparison which was calculated by using the formula:<smiles>C[As]=[Ru]N</smiles> 


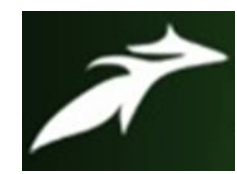

Sidharth Dash et al, International Journal of Advances in Agricultural Science and Technology, Vol.8 Issue.1, January-2021, pg. 52-65

ISSN: 2348-1358

Impact Factor: 6.057

NAAS Rating: 3.77

Where M.S. = mean score

$\sum \mathrm{fx}=$ Sum of total scores obtained by the individual $\mathrm{N}=$ Total number of respondents

\section{Ranking:}

Ranking is an expression of people ees priority about their thoughts and feelings. Ranking was done by assigning the first rank to highest mean score and the second rank to the next highest mean score and so on.( The mean score for a particular factor was worked out separately for the two areas by dividing the weighted score of the factor with the total number of respondent).

\section{Correlation and correlation coefficient:}

When an increase or decrease in one variable is accompanied by an increase or decrease in the other variate, the two are said to be correlated and the phenomenon is known as correlation.

A Pearson product-moment " $r$ " is computed by the formula.

Where,

$$
r_{x y}=\frac{N \sum X Y\left(\sum X\right)\left(\sum Y\right)}{\sqrt{\left[N \sum X^{2}-\left(\sum X\right)^{2}\right]\left[N \sum^{2}-\left(\sum Y\right)^{2}\right]}}
$$

$\mathrm{X}$ and $\mathrm{Y}=\quad$ Original scares in variables $\mathrm{X}$ and $\mathrm{Y}$

$\mathrm{N}=$ Number of paired scores

$\sum \mathrm{Y}=$ Each $\mathrm{X}$ multiplied by its corresponding $\mathrm{Y}$, then summed

$\sum=$ Sum of $X$ scores

$\sum^{2}=$ Each of $X$ squared, then summed $\left(\sum\right)^{2}=$ Sum of $X$ score squared

$\sum \mathrm{Y}=$ Sum of $\mathrm{Y}$ scores

$\sum \mathrm{Y}^{2}=$ Each of $\mathrm{Y}$ squared, then summed $\left(\sum \mathrm{Y}\right)^{2}=$ Sum of $\mathrm{Y}$ score squared

The range of correlation coefficient is between -1 to +1 . This means that -1 is perfect negative correlation and +1 is perfect positive correlation. A perfect correlation is, however, seldom achieved. A correlation coefficient to be acceptable should be statistically significant. 


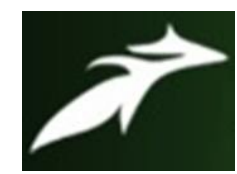

Sidharth Dash et al, International Journal of Advances in Agricultural Science and Technology, Vol.8 Issue.1, January-2021, pg. 52-65

ISSN: 2348-1358

Impact Factor: 6.057

NAAS Rating: 3.77

Otherwise, we say that no significant relationship exists between the variables.

\section{Multiple regression analysis:}

Generally, a number of antecedent variables simultaneously contribute to influence the consequent variables, as in the case under study. It is of immense practical value to know the extent to which the antecedent variables, individually or jointly, could predict or contribute towards the consequent variable. This was done by computing multiple regression analysis. If $\mathrm{Y}$ is the consequent variable and $\mathrm{X}_{1}, \mathrm{X}_{2}, \mathrm{X}_{3} \ldots$ are the antecedent variables; the multiple regression equation is given by the following formula-,

Or,

The significance of the $b$ - value was judged by calculating their respective $t$ - values and comparing them to the table, given by Fisher and Yates, with (n-p-1) degree of freedom (where, $\mathrm{n}=$ number respondents and $\mathrm{p}=$ number of antecedent variables) at $5 \%$ and $1 \%$ level of significance.

The square root of the ratio of the regression sum of squares to the total sum of squares is known as multiple correlation coefficients and is denoted by $\mathrm{R}$. The square of the multiple correlation coefficients $\mathrm{R}^{2}$ is called the multiple coefficients of determination and represents the fraction of the variation of $\mathrm{Y}$ accounted for by its joint association with the variables $\mathrm{X}_{1}, \mathrm{X}_{2}$, $\mathrm{X}_{3}$ Central to the application of multiple regression analysis is the interpretation of the final fitted model. A significant $\mathrm{F}$ - value for $\mathrm{R}$ means that the fitted model is adequate. The significance of the F- value was judged by comparing it to the table value, given by Fisher and Yates with $\mathrm{P}$ and (n-p-1) degrees of freedom (where, $\mathrm{P}=$ number of antecedent variables and $\mathrm{n}$ $=$ number of respondents) at $5 \%$ and $1 \%$ levels.

Table- 1: Descriptive Statistics of the development parameters of respondents

\begin{tabular}{|l|l|l|l|l|}
\hline Particulars & $\begin{array}{l}\text { Knowledge } \\
\text { Development }\end{array}$ & $\begin{array}{l}\text { Technological } \\
\text { Development }\end{array}$ & $\begin{array}{l}\text { Economic } \\
\text { Development }\end{array}$ & $\begin{array}{l}\text { Social } \\
\text { Development }\end{array}$ \\
\hline Mean & 2.113 & 1.828 & 1.888 & 1.983 \\
\hline Standard Deviation & 0.091 & 0.109 & 0.117 & 0.116 \\
\hline Coefficient of Variation & 0.192 & 0.199 & 0.220 & 0.231 \\
\hline
\end{tabular}

The table found higher mean score in knowledge development (mean $=2.11$ ) followed by social development (mean=1.98). The results showed higher percentage of coefficient of 


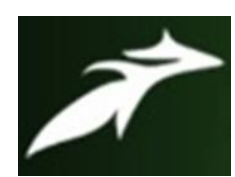

Sidharth Dash et al, International Journal of Advances in Agricultural Science and Technology, Vol.8 Issue.1, January-2021, pg. 52-65

ISSN: 2348-1358

Impact Factor: 6.057

NAAS Rating: 3.77

variation in social development $(23.1 \%)$ followed by economic development $(22 \%)$. This depicted more variation in the response of sample on those variables.

Table- 2: Knowledge development of the respondents

\begin{tabular}{|c|l|l|l|}
\hline Sl. No. & \multicolumn{1}{|c|}{ Statement } & Mean Score & Rank \\
\hline 01 & Good management practices & 2.618 & III \\
\hline 02 & Risk management & 2.603 & IV \\
\hline 03 & Primary processing activities & 1.000 & X \\
\hline 04 & Quality control & 1.000 & X \\
\hline 05 & Pest management & 2.313 & VII \\
\hline 06 & Market intelligence & 2.198 & VIII \\
\hline 07 & Increased Bargaining Power & 2.710 & II \\
\hline 08 & Business Plan & 2.382 & VI \\
\hline 09 & Group formation & 2.771 & I \\
\hline 10 & Agro-advisory importance & 2.595 & V \\
\hline 11 & Knowledge on ICT use & 1.061 & IX \\
\hline
\end{tabular}

The result found that there was remarkable knowledge development of FPO member respondents in group formation activities (mean score=2.77), better bargaining power (2.71) in price determination, good management practices (2.62), better risk management (2.60) and importance of agro-advisory information (2.6) for better production and to make agriculture more profitable with all its suitable inputs. The member respondents indicated their insufficient knowledge in primary processing activities and quality control having mean value 1 and use of ICT (mean score=1.06) in harnessing advanced agricultural information.

Table - 3: Level of knowledge development of the respondents.

\begin{tabular}{|l|l|}
\hline \multicolumn{1}{|c|}{ Category } & \multicolumn{1}{|c|}{ Frequency (Percentage) } \\
\hline High (Mean + SD) & $15(11.45 \%)$ \\
\hline Medium (Mean +_SD) & $86(65.65 \%)$ \\
\hline Low (Mean - SD) & $30(22.90 \%)$ \\
\hline
\end{tabular}

This result revealed that 11.45 percentage of member respondents have showed higher knowledge development in better farming, 22.9 percentage indicated towards low level knowledge development while a majority of 65.65 percentage member respondents indicated (C) 2021, IJAAST All Rights Reserved, www.ijaast.com 


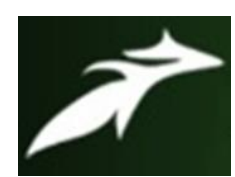

Sidharth Dash et al, International Journal of Advances in Agricultural Science and Technology, Vol.8 Issue.1, January-2021, pg. 52-65

ISSN: 2348-1358

Impact Factor: 6.057

NAAS Rating: 3.77

medium level knowledge development on better farming and technology utilization due to involvement in farmer producer organization and in its activities. The improvement in knowledge on management practices, pest management, quality control etc. might be due to the need-based training facilitated by the FPO to its members for higher production.

Table- 4: Technical development of the respondents

\begin{tabular}{|c|l|l|l|}
\hline Sl. No. & \multicolumn{1}{|c|}{ Statement } & Mean Score & \multicolumn{1}{|c|}{ Rank } \\
\hline $\mathbf{0 1}$ & Timely input availability & 2.099 & VI \\
\hline $\mathbf{0 2}$ & Extension Support & 2.435 & I \\
\hline $\mathbf{0 3}$ & Custom Hiring & 1.000 & XI \\
\hline $\mathbf{0 4}$ & Capacity Building & 2.427 & II \\
\hline $\mathbf{0 5}$ & Skill development & 2.275 & V \\
\hline $\mathbf{0 6}$ & Implementation of Good Agricultural Practice & 1.725 & VII \\
\hline $\mathbf{0 7}$ & Value addition & 1.008 & X \\
\hline $\mathbf{0 8}$ & Market information service & 2.351 & IV \\
\hline $\mathbf{0 9}$ & Price discovery mechanism & 2.374 & III \\
\hline $\mathbf{1 0}$ & Use of ICT in agriculture & 1.015 & IX \\
\hline $\mathbf{1 1}$ & Aggregation, transport and storage & 1.382 & VIII \\
\hline
\end{tabular}




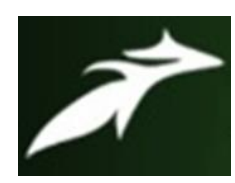

Sidharth Dash et al, International Journal of Advances in Agricultural Science and Technology,

Vol.8 Issue.1, January-2021, pg. 52-65

ISSN: 2348-1358

Impact Factor: 6.057

NAAS Rating: 3.77

The table found a higher technical development of member respondents with their involvement in farmer producer organization in getting better extension support (mean score $=2.435$ ) followed by their capacity building (2.427), price discovery mechanism literacy (2.374) and market information service (2.351). The least technical development was in custom hiring process, value addition techniques, ICT use and storage facilities. The FPO has facilitated better extension support in enhancing the skill level of the member farmers and also provided market literacy on consumer preference and price discovery at each stage of marketing which has help the member farmers in selecting the right crops and getting remunerative prices for their products.

Table- 5: Level of technical development of the respondents.

\begin{tabular}{|l|l|}
\hline \multicolumn{1}{|c|}{ Category } & \multicolumn{1}{|c|}{ Frequency (Percentage) } \\
\hline High (Mean + SD) & $19(14.50 \%)$ \\
\hline Medium (Mean+_SD) & $100(76.34 \%)$ \\
\hline Low (Mean - SD) & $12(9.16 \%)$ \\
\hline
\end{tabular}

The table revealed that a majority of 76.34 percentage of member respondents showed medium level technical development followed by 14.5 percentage in high level and only 9.16 percentage in low level of technical development with the effect of their membership in farmer producer groups.

Table- 6: Economic development of the respondents.

\begin{tabular}{|c|l|l|l|}
\hline Sl. No. & \multicolumn{1}{|c|}{ Statement } & Mean Score & Rank \\
\hline $\mathbf{0 1}$ & Access to Credit Loans through FPO & 1.000 & IX \\
\hline $\mathbf{0 2}$ & Profit Sharing among FPO members & 2.641 & I \\
\hline $\mathbf{0 3}$ & Price negotiation for the inputs & 2.481 & III \\
\hline $\mathbf{0 4}$ & Increase in production & 2.504 & II \\
\hline $\mathbf{0 5}$ & Increase in marketable surplus & 1.061 & VIII \\
\hline $\mathbf{0 6}$ & Increase in income & 2.221 & V \\
\hline $\mathbf{0 7}$ & Decrease in transaction cost & 2.458 & IV \\
\hline $\mathbf{0 8}$ & Getting good price for their product & 1.527 & VII \\
\hline $\mathbf{0 9}$ & Increase in farmer share in consumer rupee & 1.985 & VI \\
\hline $\mathbf{1 0}$ & Crop insurance & 1.000 & IX \\
\hline
\end{tabular}




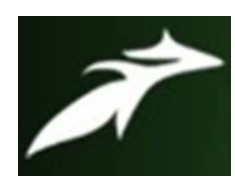

Sidharth Dash et al, International Journal of Advances in Agricultural Science and Technology, Vol.8 Issue.1, January-2021, pg. 52-65

ISSN: 2348-1358

Impact Factor: 6.057

NAAS Rating: 3.77

With fulfilling one of its mandate, it was found that FPO shared its profit among FPO members with respect to their volume of products. It has increased the faithfulness of the group and accelerates the growth of the group. The members indicated a remarkable increase in their production (mean score $=2.504$ ) followed by lower input cost (2.481) and decrease in transaction cost (2.458) due to conglomeration of a number of farmers and their all-total huge volume of products. To the member farmers, the FPO has facilitated inputs like seed, fertilizer and implements directly from the company or retailers rather than from the local markets which minimized their input costs. The huge quantity of produces of member farmers has attracted the potential buyers for better price. This has also minimized their individual transaction cost. The farmers were still showed their concern in crop insurance and credit loan facilitates.

Table- 7: Level of economic development of the respondents.

\begin{tabular}{|l|l|}
\hline Category & Frequency (Percentage) \\
\hline High (Mean + SD) & $19(14.50 \%)$ \\
\hline Medium (Mean +_SD) & $89(67.94 \%)$ \\
\hline Low (Mean - SD) & $23(17.56 \%)$ \\
\hline
\end{tabular}

It was observed from the above table that 14.5 percentage of the member respondents realised their higher economic development while 76.94 percentage of respondents felt medium level of economic development due to the impact of FPO.

Table- 8: Social development of the respondents.

\begin{tabular}{|c|l|l|}
\hline Sl. No. & \multicolumn{1}{|c|}{ Statement } & \multicolumn{1}{|c|}{ Mean Score } \\
\hline $\mathbf{0 1}$ & Increase access of small producer to new technology & 1.397 \\
\hline $\mathbf{0 3}$ & Democratic Governance & 2.290 \\
\hline $\mathbf{0 4}$ & Increased in household income & 2.511 \\
\hline $\mathbf{0 5}$ & Increased Influence & 2.588 \\
\hline $\mathbf{0 6}$ & Conservation of natural resources & 1.412 \\
\hline $\mathbf{0 7}$ & Welfare Services & 2.519 \\
\hline $\mathbf{0 8}$ & Close involvement of stakeholders & 1.664 \\
\hline $\mathbf{0 9}$ & Elimination of several layers in marketing channel & 1.031 \\
\hline
\end{tabular}

The FPO has increased its influence (mean score=2.59) among the member farmers with its welfare services (2.52) and increased household income (2.51) to a great extent through better market facilitation and enhancing all round family occupation. Democratic governance of FPO (mean score=2.29) has empowered the member farmers with management and decision capability and shared the equal status to all members. 


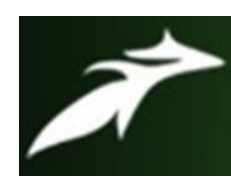

Sidharth Dash et al, International Journal of Advances in Agricultural Science and Technology,

Vol.8 Issue.1, January-2021, pg. 52-65

ISSN: 2348-1358

Impact Factor: 6.057

NAAS Rating: 3.77

Table- 9: Level of social development of the respondents.

\begin{tabular}{|l|l|}
\hline \multicolumn{1}{|c|}{ Category } & \multicolumn{1}{c|}{ Frequency (Percentage) } \\
\hline High (Mean + SD) & $28(21.37 \%)$ \\
\hline Medium (Mean +_SD) & $85(64.89 \%)$ \\
\hline Low (Mean - SD) & $18(13.74 \%)$ \\
\hline
\end{tabular}

The result found that 64.89 percentage member respondents experienced medium level social development while 21.37 percentage felt higher social development with respect to welfare services, democratic governance and involvement of all the stakeholders.

Table- 10: Correlation analysis of Independent variables with impact of FPOs

\begin{tabular}{|c|c|c|c|c|c|}
\hline Variable Names & $\begin{array}{l}\text { Knowledge } \\
\text { Development } \\
\text { (r- value) }\end{array}$ & $\begin{array}{l}\text { Technical } \\
\text { Development } \\
\text { (r- value) }\end{array}$ & $\begin{array}{l}\text { Economic } \\
\text { Development } \\
\text { (r- value) }\end{array}$ & $\begin{array}{l}\text { Social } \\
\text { Development } \\
\mathrm{t}(\mathrm{r}-\text { value })\end{array}$ & $\begin{array}{l}\text { Overall } \\
\text { development } \\
\text { (r- value) }\end{array}$ \\
\hline Age & -0.04 & -0.1 & -0.05 & 0.02 & -0.06 \\
\hline Caste & $0.18^{* *}$ & 0.09 & 0.12 & 0.12 & $0.18 * *$ \\
\hline Education & -0.05 & -0.1 & -0.02 & -0.02 & -0.06 \\
\hline Annual Income & 0 & $0.18^{* *}$ & $0.34 * * *$ & 0.1 & $0.23 * * *$ \\
\hline Family Size & -0.1 & -0.09 & -0.14 & -0.12 & -0.16 \\
\hline $\begin{array}{l}\text { Farming } \\
\text { Experience }\end{array}$ & -0.12 & -0.02 & $0.25 * * *$ & 0 & 0.05 \\
\hline House type & $0.24 * * *$ & 0.13 & $0.2 * *$ & 0.1 & $0.24 * * *$ \\
\hline Holding Size & $-0.17 * *$ & -0.05 & -0.04 & -0.18 & -0.16 \\
\hline Family Type & -0.09 & -0.09 & -0.11 & -0.18 & -0.17 \\
\hline $\begin{array}{l}\text { Extension } \\
\text { Contact }\end{array}$ & $0.3 * * *$ & $0.27 * * *$ & $0.39 * * *$ & $0.29 * * *$ & $0.45 * * *$ \\
\hline $\begin{array}{l}\text { Social } \\
\text { Participation }\end{array}$ & $0.25 * * *$ & -0.01 & 0.01 & -0.06 & 0.06 \\
\hline $\begin{array}{l}\text { Source of } \\
\text { Information }\end{array}$ & $0.16^{* * *}$ & 0.09 & 0.06 & 0.03 & 0.11 \\
\hline
\end{tabular}

Note “*”, “**”, and “***” represents significance levels at 10\%, 5\% and 1\%, respectively. 


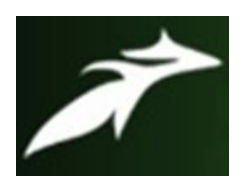

Sidharth Dash et al, International Journal of Advances in Agricultural Science and Technology, Vol.8 Issue.1, January-2021, pg. 52-65

ISSN: 2348-1358

Impact Factor: 6.057

NAAS Rating: 3.77

The data reported in the table 4.3.2 revealed that caste, house type, extension contact, social participation and mass media exposure had significant and positive relationship with knowledge development of the member respondents due to their involvement in farmer producer organisation while established negative relationship with land holding size. It indicated that the members having higher cast, better extension contact, social participation and higher mass media exposure had enhanced the knowledge level of the farmers on better cultivation practices and marketing strategy to get higher income from their produce.

The independent variables like average annual income and extension contact showed positive significant association with the technical development due to FPO. With better extension support, farmers got to know new information and technologies for better management and production leading to better income. Higher average annual income healp the farmers for higher investment in agriculture for quality inputs.

The dependent variable economic development was found to be positively correlated with independent variables like annual income, farming experience, house type and extension contact of the respondents. The variable extension contact was found to be positively correlated with social development.

The total development was found to have positive significant association with caste, average annual income, house type and extension contact. It was concluded that extension contact and average annual income of the respondents were positively influenced by the impact of the farmer producer organisations.

Table-11: Multiple regression analysis of socio-economic variables of respondents with impact of FPOs.

\begin{tabular}{|c|c|c|c|c|c|}
\hline Particulars & $\begin{array}{l}\text { Knowledge } \\
\text { Development }\end{array}$ & $\begin{array}{l}\text { Technical } \\
\text { Development }\end{array}$ & $\begin{array}{l}\text { Economic } \\
\text { Development }\end{array}$ & $\begin{array}{l}\text { Social } \\
\text { Development }\end{array}$ & Impact \\
\hline Intercept & $1.39 * * *(0.25)$ & $1.70 * * *(-0.29)$ & $0.80 * * *(0.22)$ & $1.81 * * *(0.31)$ & $1.43 * * *(0.18)$ \\
\hline Age & $-0.01(0.04)$ & $-0.06(0.04)$ & $0.01(0.04)$ & $-0.03(0.05)$ & $-0.02(0.03)$ \\
\hline Caste & $0.07 * *(0.03)$ & $0.04(0.04)$ & $0.04(0.03)$ & $0.06(0.05)$ & $0.05 * *(0.03)$ \\
\hline Education & $-0.01(0.02)$ & $-0.03(0.03)$ & $-0.02(0.02)$ & $0.01(0.03)$ & $-0.01(0.020$ \\
\hline $\begin{array}{l}\text { Average Annual } \\
\text { Income }\end{array}$ & $0(0.03)$ & $0.07 * * *(0.02)$ & $0.11 * * *(0.02)$ & $0.05^{*}(0.03)$ & $0.06 * * *(-0.02)$ \\
\hline Family Size & $-0.04 *(0.02)$ & $-0.03(0.02)$ & $-0.03(0.02)$ & $-0.04(0.03)$ & $-0.04 * *(0.02)$ \\
\hline Farming & -0.03 & -0.02 & $0.09 * * *$ & -0.01 & 0.01 \\
\hline Experience & $(0.02)$ & $(0.02)$ & $(0.02)$ & $(0.03)$ & $(0.02)$ \\
\hline Type of House & $0.13 * * *(0.04)$ & $0.04(0.04)$ & $0.08 * *(0.04)$ & $0.07(0.04)$ & $0.08 * * *(0.02)$ \\
\hline Land Holding & $-0.05^{* *}(0.02)$ & $-0.03 * * *(0.02)$ & $-0.04 *(0.02)$ & $-0.07 * * *(0.03)$ & $-0.05 * * *(0.02)$ \\
\hline Extension Contact & $0.11 *(0.05)$ & $0.15 * *(0.06)$ & $0.31 * * *(0.05)$ & $0.19 * * *(0.07)$ & $0.19 * * *(0.04)$ \\
\hline $\begin{array}{l}\text { Social } \\
\text { Participation }\end{array}$ & $\begin{array}{l}0.09 * * \\
(0.05)\end{array}$ & $\begin{array}{l}-0.07 \\
(0.05)\end{array}$ & $\begin{array}{l}-0.05 \\
(0.04)\end{array}$ & $\begin{array}{l}-0.08 \\
(0.05)\end{array}$ & $\begin{array}{l}-0.03 \\
(0.03)\end{array}$ \\
\hline $\begin{array}{l}\text { Mass media } \\
\text { exposure }\end{array}$ & $\begin{array}{l}0.06 \\
(0.09)\end{array}$ & $\begin{array}{c}0.06 \\
(0.1)\end{array}$ & $\begin{array}{l}-0.12 \\
(0.07)\end{array}$ & $\begin{array}{l}-0.03 \\
(0.12)\end{array}$ & $\begin{array}{l}-0.01 \\
(0.06)\end{array}$ \\
\hline
\end{tabular}




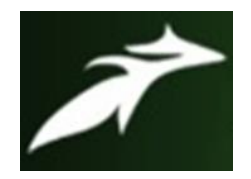

Sidharth Dash et al, International Journal of Advances in Agricultural Science and Technology, Vol.8 Issue.1, January-2021, pg. 52-65

ISSN: 2348-1358

Impact Factor: 6.057

NAAS Rating: 3.77

\begin{tabular}{|l|l|l|l|l|l|}
\hline Material Possession & $-0.09(0.12)$ & $-0.04(0.14)$ & $0.16(0.11)$ & $-0.27 * *(0.13)$ & $-0.06(0.08)$ \\
\hline N & 131 & 131 & 131 & 131 & 131 \\
\hline R2 & 0.29 & 0.19 & 0.44 & 0.22 & 0.42 \\
\hline
\end{tabular}

Note: “*”, “**” and “***” represents significance levels at 10\%, 5\% and 1\%, respectively. Figures in the parenthesis indicates standard error.

Regression analysis was carried out to elicit the causal impact of socio- economic variables selected for the study on the consequent factor impact of FPO with respect to development in knowledge, technological, economic and social aspects of the respondents.

It was observed that caste, family size, type of house, land holding, extension contact and social participation of the member respondents had significant regression effect on their knowledge development. Better social participation and extension contact had exposed the respondents to innovations and modernisation, leaded to acquisition of more knowledge. The R Square value being .29 , it can be concluded that this conglomeration of socio-economic variable has attributed 29 percent to knowledge development aspect of the respondents.

The above table showed that independent variables like annual income and extension contact of respondents contributed higher variance to the consequent variable technological development with the effect of their involvement in farmer producer organisation. It was observed that respondents with higher average annual income indicating able to make higher investment and better extension contact have benefitted more in their technological development due to the capacity building and modern technologies facilitated by the FPOs. The R Square value being .19 , showed about 19 percent variance attributed to technological development by the conglomeration of socio- economic variable of the respondents.

Among the 12 variables, average annual income, farming experience, type of house average land holding and extension contact had recorded significant regression impact upon economic development of the member respondents. The $\mathrm{R}$ square value being 0.44 , it is concluded that the conglomeration of the causal factors together has attributed to 44 per cent. So, it can be concluded that the socio-economic variables had considerable influence in accelerating economic development of the FPO members.

With the R square value of 0.22 which indicated that 22 per cent of variance were contributed by the conglomeration of all the socio-economic variables while independent variables like annual income, average land holding, extension contact and materials possession had significant regression effect on social development aspect of the respondents.

The independent variables like caste, family size, average annual income, type of house, average land holding and extension contact had recorded significant regression effect on impact of FPO on its members. The R Square value being .42, showed about 42 percent variance attributed to impact of FPO by the conglomeration of socio-economic variable of the respondents. So, it can be concluded that the socio-economic variables of the member respondents had considerable influence on impact of FPO in accelerating knowledge, technological, economic and social development of the FPO members. 


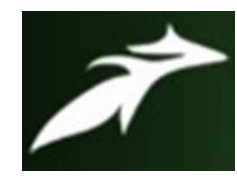

Sidharth Dash et al, International Journal of Advances in Agricultural Science and Technology,

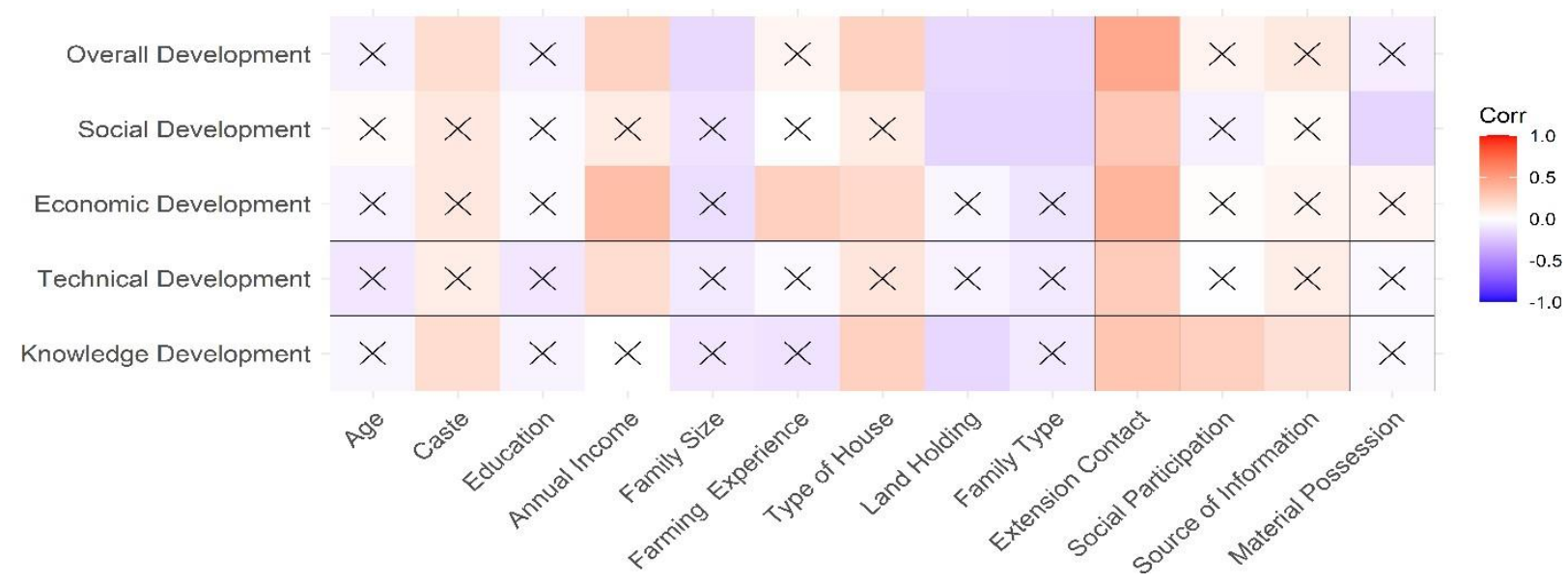

Notes: The red hue represents positive correlation, and the blue represents negative correlation. The cells with cross mark have non-significant correlation. The significance level was set at 10 per cent.

\section{CONCLUSION:}

The agricultural sector in India is hampered by natural calamities and monsoon uncertainty. The absence of adequate marketing infrastructure, presence of middleman, lack of collectivization effort leads to grab less marketing opportunities and earnings. To overcome this situation, the concept of farmer producer organisation (FPO) was developed and implemented. This study found remarkable impact of FPO on its members with respect to technical and economic development enhancing annual income with a better facilitation of marketing of produce. The members have harnessed the opportunities in conglomeration of a number of farmers in reducing their input and transport cost and capacity building on innovation technologies for better production. The more benefits were obstructed by some of the technical and economical constraints. The complex procedure and collateral issues in loan access has pushed the farmers for external loans with high interest. Still the farmers are facing marketing issues in getting remunerative prices for their products due to exploitation of the middlemen and lack of awareness of the farmers regrading market availability and demand. There is a need for a greater recognition of the importance of linking with other actors who are potential sources of services, information, technical support and market outlets. More importantly, from the supply side, strengthening the capacity of service providers and external actors (government, NGO, church-based, and private sector) will be needed to complement strategies supporting linkages. State governments may encourage FPOs to perform as agencies for procurement operations and extend to develop forward linkages through storage, postharvest processing, value addition for enhanced access to fair market. 


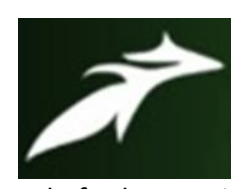

Sidharth Dash et al, International Journal of Advances in Agricultural Science and Technology, Vol.8 Issue.1, January-2021, pg. 52-65

ISSN: 2348-1358

Impact Factor: 6.057

NAAS Rating: 3.77

\section{References}

[1]. Ampaire EL, Machethe CL and Birachi E.2013. The role of rural producer organizations in enhancing market participation of smallholder farmers in Uganda: Enabling and disabling factors. African Journal of Agricultural Research. 8(11): 963-970.

[2]. Ahire RD and Kapse PS. 2015. Socio-economic Impact of Commodity Interest Group among Pomegranate Growers, AGRESCO 2016-2017.

[3]. Akhilesh. 2017. Formation of Farmer Producer Organisations and its Impact on the Development of Sustainable Crop Production in Karnataka, Institute of Agri Business Management, Swami Keshwanand Rajasthan Agricultural University, Bikaner, Rajasthan.

[4]. Esham M and Ushami K. 2007. Evaluating the performance of farmer companies in Srilanka: A case study of Ridi Bendi Ela farmer company. Journal of Agricultural Development Studies 16(2): 175-176.

[5]. Evengy L and Thomas B. 2016. Networks of rural producer organizations in Uganda: What can be done to make them work better? World Development, 78: 572-586.

[6]. Mondal A. 2010. Farmer producer company (FPC): concept, practice and learning-a case from action for social advancement. Financing Agriculture. 42 (7): 29-33.

[7]. Murray EV. 2009. Linking farmers producing rainfed crops with markets-A new paradigm.

[8]. Naik JL. 2011. Role of NCDEX Spot Exchange Ltd. (NSPOT) in Tur marketing in Gulbarga district: An Economic Analysis, MBA Thesis, University of Agricultural Sciences, Dharwad.

[9]. Pustovoitova N. 2011. Producer Company as an Institutional Option for Small Farmers in India, M.Sc. thesis.

[10]. Radhika Rani C and Reddy A. 2014. Producer organisations in Indian agriculture: Their role in improving services and intermediaries. South Asian Research, 34(3):1-16.

[11]. Raghuprasad KP, Umamahesh AB and Mohan IN. 2004. Self Help Groups: strengths and constraints in introducing agro based enterprises, National Seminar on Contemporary challenges for Indian Agriculture and Rural Development, Univ. agril. Sci., Dharwad.

[12]. Rani Nidhi, et al. 2017. Formation of Farmer Producer Organisations and Its Impact on the Development of Substainable Crop Production in Karnataka. International Journal of Agriculture Sciences, 9(4),3735-3738.

[13].Ray GL, Chatterjee P and Banerjee SN. 1995. Characteristics of the client system. In: Technological gap and constraints in agricultural technology transfer. Calcutta, 12-14.

[14].Sahu S. 2014. Socio economic impact of Farmers' Organisation, Indian Research Journal of Extension Education, 9(2): 2031-2032.

[15].Sarthak G and Mishra S. 2011. Size Class and Returns to Cultivation in India: A Cold Case Reopened, IGIDR working paper No. WP2011-27, Mumbai.

[16].Shiferaw BA, Obare GA and Muricho G. 2006. Rural institutions and producer organizations in imperfect markets: Experiences from producer marketing groups in semi-arid eastern Kenya.

[17]. Shivani V, Ramandeep S and Sidhu MS. 2017. A case study on selected farmer producer organization for promoting processed food in Punjab. Indian Journal of Agricultural Marketing. 31(1): 15-23.

[18].Singh S. 2008. Producer companies as new generation cooperatives. Economic and political weekly, 22-24. 